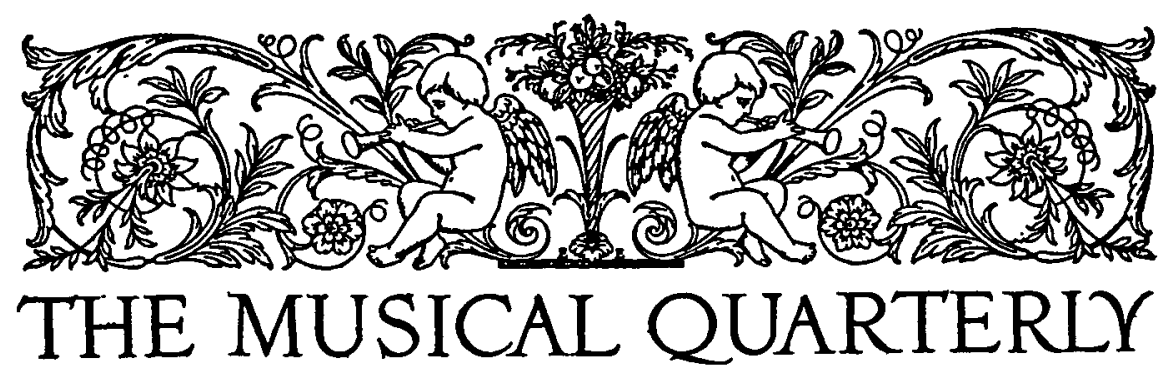

VOL IV

OCTOBER, 1918

NO. 4

\title{
MUSIC WE SHALL NEVER HEAR
}

\section{By CARL ENGEL} rêver.

L'orgue de Barbarie, dans le crépuscule du souvenir, m'a fait desesperément

Stephane Mallarmé

COME of us, who have not yet been privileged to enter into direct communication with the spectral world, still find in dreams the strangest of their terrestrial experiences. And of all dreams, those that we are consciously spinning in moments of an intensified wakefulness-which has of sleep the peculiar quality of rendering us insensible to our immediate surroundings, while it begets a swifter pace of thought than does the stimulating drug - those dreams, indeed, are the most wonderful and most inexplicable.

It was not, as in the case of Mallarmé, a hand-organ, with its joyously vulgar tunes, with its old-fashioned and banal song of the faubourgs, which made me dream so desperately. Nor did it happen in Mallarmés favorite season, the dying days of Summer. It was on an afternoon in Spring, at the side of a crackling fire, for which a wet and chilly relapse into Winter formed a more than plausible excuse. And it was a story by Maurice Renard, "La Mort et le Coquillage," which started all the trouble and sent me on the melancholy and meandering road to music we shall never hear. But the story, of course, is far more musical than any hand-organ can ever expect to be; and I feel that I should here reveal a little about this extraordinary tale, which is the fourth in a book of seven, one weirder than the other, and all by the same author. Nerval, a composer, died of what his friends regard as a stroke of apoplexy. He had been at work, 
for years, on his masterpiece, "Amphitrite." The prelude, representing Neptune's train, is a gorgeous riot of tones, of strange, unheard-of harmonies, leading to the brutal chords with which the Tritons announce the approach of the Sirens. But at this point the composer's invention stopped short-he is incapable, is utterly unable to write the haunting song of the Nereids. It is a large sea-shell which came from the beach of Salerno, picked up one evening from the mantlepiece in Nerval's room, that suddenly exerts its unsuspected spell over the despairing musician. He casually holds it to his ear, and what he hears is indescribable. He is hypnotised. Like a prehistoric phonograph, the shell has preserved the sound of miraculous voices, and there can be no doubt to whom they belonged. He rushes to the piano and tries to write down "la divine clameur sexuelle" of these women that followed the God of the Ocean. The floor is soon littered with sheets of paper, covered with vain attempts at a transcription of this incredible chant. At two o'clock in the morning, Nerval, exhausted, gives up the quest; at four he begins to tremble with fever; at half-past five he falls against the marble mantle-dead. The shell drops to the floor and breaks into a thousand splinters. The narrator ends with the question: "Pourquoi riez-vous?" and I almost believe that you are smiling, too. But that is my fault, my imperfect sketch of an astonishing tale. Read it, and you will not laugh. More than that, you will understand the reason for this long preamble.

Supremely futile as it may appear to speculate on the sweetness of the Sirens' song, there is no denying that futile occupations have a charm peculiarly their own. I am inalienably attached to them, and $I$ have long since learned that what my sterner friends brand as a "waste of time," are the happiest hours of my life. The story finished, I began to look into the ever-shifting flame, until my pupils seemed to burst my head, until my ears began to catch long-forgotten sounds, which the relentless tide of time and fleeting fashion had swept into the background of oblivion.

I realize that if I want to tell you something of my shadowy escapade, I must be very careful not merely to offer a long list of names and titles, plucked at random from the past. For the graveyard of music is a spacious acre, and labyrinthian paths wind through myriad rows of unremembered tombs. Many stones have crumbled; they bear no longer the slightest trace of deed or date. Too many, alas, of these graves are the tragic, though well-deserved, repositories of still-born effort. Much music 
lies buried there which never should have seen the light of day, which never held a spark of life. Countless fresh mounts testify to an ever increasing mortality. On the other hand, there remains not a little music which is enjoying an unnatural longevity. Illadvised performers and conductors drag it from the sick-room with the fondness which some people have for exhibiting their decrepit relatives of remote birth. It should have been put by long ago. We may be justly grateful if we never hear it.

But that the Sirens' song should have perished, unrecorded, is certainly regrettable, in spite of its reputed dangerous effects. Malicious tongues have it that the fatal consequences were due to the extreme impurity of intonation indulged in by the ladies . . . listeners preferring to commit self-murder rather than stand the torture. This theory presupposes such an unreasonably superior sensitiveness on the part of ancient tars, that I am wholly disinclined to give it serious consideration. I deplore the loss of all the music to which Greek mythology makes such frequent and glowing reference.-And yet, was not perhaps Arion overrated? Would Orpheus, in our day, still work his magic? 'The widowed bard charmed beast and tree; he dared descend to Hades. Would he have the courage to step before that modern monster, a concert audience composed of critics and connoisseurs?- Hellas was not the only place of musical prodigies. The ancient history of the Hebrews tells of remarkable feats. What did the trumpets blow which felled the walls of Jericho? Some learned Rosecrucian might possibly tell you that these destructive buglers carefully ascertained the "vibrations" of the city's mural defenses, and then lustily blew a chord which corresponded to their number. Did King David, on his harp, use the little finger as well as the others? What was it the Children of Israel refused to sing, by the rivers of Babylon, when their captors required of them one of the songs of Zion, and a song of mirth above all?-The answer is difficult, perhaps impossible. Still, we are here no longer upon entirely uncertain ground. Many of the traditional tunes preserved in the Jewish worship, date from a dim and distant day. Some of them are melodies of surpassing beauty and true Oriental line, though hardly the expression of great mirth. They would suffice to make one feel, in looking backward over many centuries of musical development, that there must have been things for the disappearance of which we have good cause to be sorry. We have not missed so much, perhaps, in not having heard Nero sing his own odes with a wine-worn voice. He had spared no effort to cultivate the art of singing and had placed 
himself in the hands of Rome's ablest vocal instructors. Did he not, upon the advice of one of these worthies, lie flat on his back for hours, supporting the weight of heavy stones on his chest, to strengthen the muscles of his diaphragm? It appears that the "methods" of singing teachers have not materially changed throughout the ages. It is difficult to conceive how Italy, how the whole of Europe could have offered these maestri a large enough field of operation, if their countryman Columbus had not opportunely discovered America for them.I will confess that I would give much to have heard Saint Cecilia extemporize upon the organ, if for no other reason than to be able to disprove the contention of those hypercritical historians who argue that the titulary saint of music did not know one note from another, and that no Cavaillé-Coll or Skinner existed in her day. Be that as it may, she was fortunate in having the most famous artists idealize her in painting and sculpture, which gave her as much posthumous advertising as some of our living and constantly photographed organists attain only by the ruthless dissemination of their innumerable poses.

But let us take a short cut to yonder corner of the cemetery, with its long tiers of urns, of table-tombs, of weeping angels, shaded by willow trees and yews. It is not very long ago that these names which now you can hardly distinguish, were on everybody's lips, were praised and worshipped. What are two hundred years? They are enough to wipe out everything except a short, cold, matter-of-fact note in the Biographical Dictionary. The transitoriness of mundane glory is nowhere demonstrated with more cruel certainty than in the realm of arts and letters. Nature's law is unalterable. The stately sunflower that proudly raised its head must sooner or later fade and wither, like the violet, of proverbial modesty, that bloomed in a secluded nook, and was content in pouring out its little soul of nectar. In fact, I am inclined to believe that, of the two, the violet's fate is, if anything, the less bitter. For though its perfume be but a memory, we are apt to keep it pressed between the leaves of a beloved book. The sunflower knows no such sentimental aftermath. Sparrows come, and pick the seeds.

Charles VI, of the House of Habsburg, had succeeded his brother Joseph as Roman Emperor of the German Nations. He inherited not only a throne, but wars to wage and arts to cultivate. He neglected neither. The affairs of the Netherlands and of Spain having been settled, the Emperor, nine years after coming into power, decided to take formal possession of one of his 
most valuable crown-lands, and in 1723 he went to Prague for his coronation as King of Bohemia. To flatter the crowd and to impress the kings, his brothers, he planned to have the ceremonies attended by unusual pomp and brilliance. No function of this sort was complete without music, and it had to be music in its most regal form, the opera. Born at the court of Florence, the opera has always remained a princely offspring, notwithstanding all efforts to breed a species that would more nearly approximate popular taste, and that could be maintained by popular support alone. Charles was very fond of operas and had his private composer supply him with a new one whenever wanted. Johann Joseph Fux was undoubtedly an excellent musician, and Vienna had no other to compare with him.--In 1714 Fux wrote an opera, "Elisa," for the birthday of Charles' aunt, Archduchess Elizabeth Christina, which made a sensation. The Emperor was so pleased with the work, that at the third performance-being himself a dilettante of no mean ability-he played the clavecin in the orchestra, while the composer turned the pages. Fux, to compliment his imperial master, remarked what a pity it was that his Majesty had not become a Kapellmeister. But Charles is said to have replied that he was perfectly satisfied with his position. -For the festivities in Prague, Fux, who was then sixty-three years old, had written "Costanza e Fortezza." The Emperor had spared no costs to engage the best singers of the day. An orchestra of more than a hundred men had been assembled from all over Europe, under the leadership of Caldara. Among the violinists was Tartini. Quantz had come from Berlin to play the flute. With him journeyed Weiss and Graun. Prague was a beehive of musicians. ${ }^{1}$ The excitement was great, for rumor had it that Fux was too ill with the gout to leave Vienna. But the Emperor would let no gout interfere with his plans to honor his dear composer, and by his orders Fux was carried in a sedanchair all the way from the Donau to the Moldau capital. At the gala performance, which took place in the open air, it was not the Cardinal-Primate of Prague nor the Elector of Bavaria who sat next to the newly-crowned King of Bohemia, but Johann Joseph Fux, musician, with his feet bandaged in cotton. Quantz, to whom we owe many sagacious observations on the music and musicians of his time, wrote about this opera: "The composition is more churchly than theatrical, but very splendid." Quantz.

'"History does not furnish a more glorious event for music, than this solemnity. nor a similar instance of so great a number of eminent professors, of any one art, being collected together."-Dr. Charles Burney: "The Present State of Music in Germany. etc.," London, 1773, Vol. II. 
did not care very much for Tartini's playing. He admired the beautiful tone and finished execution, but thought his style dry and lacking in charm. Another violinist in the orchestra was Nicola Matteis, who had written the ballet music interpolated in "Costanza e Fortezza." Matteis was born in London, of an Italian father. In 1737, at Shrewsbury, he gave young Burney lessons in French and in music. Burney tells us that he excelled in playing Corelli's sonatas. We still occasionally hear Corelli's "Follia." But of Matteis' music there remains as little as of the many operas by the great Fux, in spite of the fact that Fux was probably one of the most celebrated men of his age, the author of a remarkable treatise on composition, printed at the Emperor's expense, a monumental work for any theorist to have written, long used as a text-book. Mozart and Haydn studied it.- Upon reflection: theory has a wicked way of avenging itself. The prospects of André Gédalge might be brighter, had he not given us "La Fugue," one of the best books on the subject. There might be hope even for Arnold Schönberg, were it not for his clever "Harmonielehre."

I have mentioned Quantz. His long association with Frederick the Great is known. Frederick's passion for the flute was pathologic, as was his attachment to dogs. His greyhounds accompanied him on campaigns, following the King's traveling coach in a landau of their own, with two footmen in the back who were strictly enjoined not to address the royal favorites with the too-familiar "thou." His flute was Frederick's inseparable companion, until he began to lose his teeth.

It is half-past five in the afternoon. A rich sunset glow is painting fireworks upon the tall French windows of Sans-Souci, which rises serenely above the crest of its little hill. Quantz and Charles Philip Emmanuel Bach-more famous in his lifetime than his father-are slowly ascending the vine-covered terraces that lead to the castle. They are lost in conversation. On each new level they stand a while and talk. Quantz is telling Bach of his trip to Italy, in 1725, and of his great admiration for old Alessandro Scarlatti, whom he visited in Naples and to whom he was introduced by Hasse. That name irritates Bach. He will have nothing of Hasse, even though the people go wild over his music, and though Philip V, at the Escurial, suffering from manic depression, can be induced to go to sleep, every night, only after hearing the glorious castrato Farinelli sing an aria from one of Hasse's operas. These tunes are superficial, too sugary and Italian. They will not live. Musique à la mode is ephemeral stuff. 
And as to the fabulous sum which Hasse and his wife Faustina. are drawing at Dresden, it is preposterous. Quartz promptly changes the subject and tells of his love affair at Naples: how his life was threatened by a jealous rival, how he had to flee to Rome. They laugh-but the proximity of the august presence quickly stifles their merriment. Sentinels are posted on the highest terrace, lackeys flank the portals. Quantz and Bach enter the antechamber and exchange greetings with the courtiers. It is. only petit cercle this evening. A member of the Academy of Berlin, Dutchman by birth; an English officer, just arrived, the bearer of a diamond-studded snuff box with the miniature of George II and a letter from His Britannic Majesty; a General of the Guards, who fears the Austrian fire less than these musicales; two chamberlains-and the illustrious Monsieur Voltaire. These form the audience. No women. The subdued chatter in the antechamber continues while the King is heard preluding and practicing scales, preparatory to the concert. At the stroke of six the doors of the music room open. Frederick, flute in hand, graciously receives his bowing guests. The candles in the large glass chandelier sparkle in the hundreds of crystals. A silver candelabra is placed on a little mahogany table next to Frederick's music stand of rose wood, inlaid with ivory, a present from his sister, the Margravine of Bayreuth. The walls are decorated with lovely boiseries, copied from the rooms of Louis at Versailles, on a sideboard stands a beautiful vase, the work of the young china manufactory of Berlin, in imitation of the Bourbons' older Sèvres. And the French philosopher completes the setting for this imported Kultur. Only the music is German, though that bears strong transalpine traces. The program consists of three concertos for flute and clavecin. The first and third are by Quantz. The second is by the King, that is, he has sketched out the flute part, and Agricola, pupil of Johann Sebastian Bach, has provided the accompaniment. This is entrusted to Charles Philip Emmanuel Bach, playing one of the new "fortepianos" made by Gottfried Silbermann. He has a hard task, since the King is somewhat absolutistic in his tempi. Quantz, unperturbedly, beats time. But that is not his sole charge. The piece ended, he is the only one who is permitted to say "bravo" or express any praise for the royal flutist, it being taken for granted that all the other people present know less about flute playing than he does.-Friedrich Christian Fasch, who since $\mathbf{1 7 5 6}$ alternated with Bach every month in accompanying the King, at his first appearance, unwarned, burst into loud applause, which nearly cost him his position.-After the 
third concerto has been finished, a few words are exchanged. The King has a jest for Voltaire, to which the Frenchman answers with an epigram. The English officer is the recipient of a kind word of thanks. Then the doors open again, and in the antechamber wait three couriers with dispatches from Silesia, Poland and St. Petersburg. They turn with a click of their heels and spurs, and follow the King who is humming the Andante from the last concerto on the program. And Quantz wrote something like three hundred for him!

Frederick had one great admirer-not as a flute player, but as an engineer of battles-and that was Bonaparte. Napoleon visited the dead King's Sans-Souci, and the rock crystals on the lustre in the music room gently trembled when the footstep which made Europe quake, resounded in Frederick's sacrosanctum. That night Napoleon had his field-bed placed in the late King's chamber. Did he dream of flutes or flintlocks?

There are other questions relating to Napoleon and music which are still unanswered. Frédéric Masson, who has investigated everything concerning the great Corsican, his person, family, household and reign, including the price paid for his socks and razors, has left here a lacuna. It seems fairly well established, though, that Napoleon did not have real understanding or taste for music, but that he admitted its value, and even its necessity, in certain circumstances. He did not care for Cherubini; in fact, he harbored an unexplained animosity against him. But he affected the keenest admiration for Paër. After a performance of Paër's "Achilles" at Dresden, in 1806, Napoleon, with the right of the conqueror, claimed the composer from the King of Saxony and gave him a brilliant position. Paèr had to follow the Emperor to Posen and organize musical entertainments, between battles and diplomatic conferences, probably more because it looked well in the eyes of the awe-struck nations, than on account of an unquenchable desire on Napoleon's part to be soothed by dulcet strains. He very seldom stayed for the whole of any concert given at the Tuileries. But at St. Cloud, among his family, he demanded, if he tid not enjoy, "a little music." $\mathrm{He}$ liked to hear his stepdaughter and sister-in-law, Hortense, sing him Italian romances, which she accompanied herself. Hortense Beauharnais, wife of Louis Bonaparte, Queen of Holland, is said to have had a very pleasing voice, which she inherited from her mother, whose bad teeth and beautifully modulated speech were the occasion of much contemporary comment. Hortense even composed, at least she is reputed to have written the well-known 
air "Partant pour la Syrie" in collaboration with Louis Drouet, a mere boy when he was made solo flutist to the King of Holland and "musical secretary to the Queen," later entering the services of Napoleon, and finally being transferred to Napoleon's sister, Pauline Borghese. His life was full of adventure; in 1854 he visited New York. Another sister of Napoleon, Elisa Bacciochi, had at her miniature court in Lucca no less a musical entertainer than Niccolo Paganini. He played three evenings a week. But he had to avoid harmonics. For Paganini's flageolets made poor, hysterical Elisa swoon.

There is one instance, however, where Napoleon showed serious preoccupation with music. It was at the eve of his expedition to Egypt, shrouded in impenetrable mystery. With the thoroughness which marked everything that he undertook, he wanted historians, scientists, artists, poets and musicians to accompany him to the Pyramides. Arnault, in his "Souvenirs d'un Sexagénaire," tells of these elaborate preparations. Bonaparte had declared: "Il nous faut un barde qui chante d̀ la tête des colonnes." Beside the poet and composer he wanted a singer. All three were to be attached to the First Consul's own person, and were to receive 6,000 francs each, in addition to their regular salary. Ducis pleaded old age, Méhul too much work, and Lays, with the star-tenor's characteristic regard for the interests of the public, claimed that a sea voyage might cost him his voice. Méhul recommended Henri-Jean Rigel, "habile professeur de piano," who conducted the opera installed at Cairo and gave there his own "Les Deux Meuniers" in 1799. The singer chosen was Guillaume André Villoteau, who had been choir boy, dragoon, student of medicine, and who achieved fame with his studies of the music and musical instruments of Egypt. What an enterprise, and what a stage-manager was Napoleon! Picture him on board the Orient, a night of Mediterranean splendor, his generals grouped around him, eager expectation in the mind of everybody, and Villoteau calmly singing an air from "Bélisaire" by Philidor, prolific opera composer and champion chess player of the world. Méhul, whose setting of André Chénier's "Chant du Départ" was one of the grand songs of the Revolution, had obtained his release only by promising Napoleon that he would write march tunes for the French armies. Did he write any? What has become of them? Did Napoleon, on his white horse and in his green chasseur uniform, enter Berlin to the tune of one of them? When the circumspect Prussians returned the visit, they had provided a "Pariser Einzugsmarsch." Did Dr. Richard Strauss 
write, upon all-highest command, a new and modernized version for use in August 1914? No doubt, with the rest of the war plans, arrangements were completed for a musical program befitting the hoped-for event?

The whims of Bellona are strange. Napoleon, after three days of carnage at Leipzig, in October 1813, saw his luck turn. He was beaten by his father-in-law, Emperor Franz of Austria, musical amateur and quartet fiend. . Franz entered the city, which the fleeing French were leaving, with the remark that at last he would find leisure to play a little chamber music again. The imperial quartet was always behind the firing line. At the head of it -if there could be another head than the Emperor himself-was Franz Krommer. Born in 1759, he was only three years younger than Mozart and he survived Beethoven by four years. Showing in his early youth great talent for the violin, he was brought up and kept by the munificence of rich noblemen, until he obtained a sinecure at the Viennese court, in 1812, as "door keeper of the royal bedchamber." In 1814 he was named Hofkapellmeister, a title which has covered a multitude of mediocrities. But Krommer was by no means considered such in his lifetime. On the contrary, he enjoyed the greatest popular favor. He was the composer of chamber music par excellence. He is responsible for no less than twenty-two string quintets and more than sixty string quartets. While Beethoven's quartets were understood and lauded by a few, Krommer's were played literally wherever four people got together to scrape the catgut, and, in those days, that meant everywhere. Quartet playing, in the period of transition from clavecin to hammer-klavier, from Silbermann to Erard, had become an epidemic. It was the house music of rich and poor, of cultured and simple folk. Musicians played Mozart, Haydn and Boccherini. Amateurs had Rosetti, Feska, the two Rombergs, Gyrowetzthe last of whom wrote thirty symphonies, seventy works of chamber music, lived from 1763 to 1850, and dismissed Beethoven, Weber and Schubert as "chaotic." They had furthermore Pleyel, Rode, Neubauer and Onslow-poor Onslow, the prototype of the highly cultivated and refined composer, the pet of society, admired for his "originality," called to succeed Cherubini at the Institut de France, and soon forgotten. Musical history is full of Onslows!

We can hardly conceive how difficult it was for Beethoven to break up this cohort of quartetists, and it is not surprising that these difficulties should have made him feel disappointed and embittered. H. W. Riehl vouches for the truth of the story according to which both Krommer and Beethoven were guests, one 
evening, at Count Lichnowsky's palace in Vienna. During the opening number of the program, a quartet by Krommer, Beethoven showed such undisguised contempt for the less gifted but more popular colleague, by talking and sneering, that the host had to take him to task.

Among the many stars of various magnitudes which studded the musical firmament of Vienna, at the beginning of the 19th century, there was none perhaps who with a gentle little twinkle succeeded in producing as dazzling effects as did Sigismund Neukomm. Josef Haydn had been a father to him and taught him all that could be taught. After journeys in Sweden and Russia, Neukomm arrived in Paris about 1812. Talleyrand, the machiavellian, who was the only one to see beyond Napoleon, had just lost his private pianist, Johann Ladislaus Dussek. Friends recommended young Neukomm, and he obtained the position. Talleyrand became very fond of him. He took him along to the Congress of Vienna, and there a Requiem for Louis XVI, composed by Neukomm, was sung at St. Stephens before an audience of kings and princes. Several hundred singers took part in this memorable performance. And to think that for such an occasion no worthier composer could be found. Neukomm traveled much. He went to Brazil, in 1816, with the Prince of Luxembourg, Ambassador of France. In 1826, he saw Italy. Walter Scott met him the year after. He accompanied Talleyrand to London in 1830 , and liked England so well that he settled there. He visited Algiers, Constantinople, Greece, and was on the point of embarking for New York when sudden illness overtook him in Manchester. He probably wrote more than one thousand compositions. To this day; the Universal Catalogue of Pazdireck contains three full pages listing works by Neukomm which were evidently published at some time or other. Neukomm wrote songs and choruses to texts in German, French, Latin, Russian, Italian, Bohemian, Portuguese and English. Have you ever heard any one sing them? Fétis, who saw him in London and later, in his travels, at Paris and Munich, unwittingly pronounces judgment over this amiable, generous, tactful man by calling him "un artiste respectable." In the fight for the fittest the respectable artist has slight chances to survive.

Fétis, the incomparable lexicographer, in his arduous researches must have been appalled by the number of respectable artists he encountered, and by the vast quantity of their music which is hardly remembered by name and of which never a note will sound again. And since he laid down his pen, the amount 
has grown incessantly. But there are things that Fétis heard, which we shall never hear, and which we may well envy him. Would you not like to have been at Lord Saulton's, in 1829, the night when Fétis accompanied at the piano Henriette Sontag and Marie Malibran who sang a duet from Rossini's "Semiramide"? I should. And I should also like to have seen Henriette's, then Countess Rossi's, return to Covent Garden in Donizetti's "Linda di Chamounix," when the Grand-duchess of Strelitz, Princess of Cambridge, had secretly commanded London society to be in their seats at the opera when the overture began, and to rise to their feet when the star appeared. That night, between the acts, even old Wellington, the Iron Duke, hobbled behind the scenes to kiss the tips of Henriette's fingers.

The romance of great singers is a fascinating tale retold on a thousand nights and one. There are lesser lights with whom I should be fully contented, if only they would shine into the dark and dusty recesses where gems are hidden and are persistently overlooked for the sake of obvious and tawdry Brummagem, that basks in the sun of popular approval. Shall I ever hear Schumann's "Im Zwielicht" and "Auf einer alten Burg"? Will some one sing me, for my instruction if not for my edification, the three or four settings that Schubert made of Goethe's "Erlkönig"? When will singers realize that the loveliest of Faurés songs are not among the scant half dozen which form the sum of their exploring? Singers would derive greater help from looking into a geographical atlas than from the study of publishers' announcements. I wish that inquisitive sopranos and venturesome baritones-and there exist such anomalies-would see if there is anything tempting by Erkki Melartin, Andreas Hallén, Wilhelm Stenhammer and Ture Rangström. There are songs by Albeniz, some to Italian words which are poor, one to English words which is exquisite. The bizarre Szymanowski and the austere Medtner have written for the voice. There are said to be manuscript songs by Scriabin in the possession of his widow. To which of his three periods do they belong?-There are hundreds of songs, some interesting, some beautiful, classic and modern, that no one takes the trouble to learn, and that probably we shall never hear.

A recent recital program contained a song by Augusta Holmès, once a sure winner, now but seldom sung. It recalled to my mind the rôle she played in the life of Henri Regnault, the painter with a tenor voice. Regnault had twice unsuccessfully competed for the Prix de Rome. His third attempt, in 1866, was threatening to be another failure, when one evening, during the concours, he 
met at Mme. de Sainbris' the young composer whose strange and lovely physiognomy captivated him. He made two sketches of her that night and in twelve days he completed the painting, "Thetis handing the arms to her son Achilles," and the goddess bore the traits of Augusta Holmès. He won the coveted prize. The letters which he wrote to his father and friends from the Villa Medicis contain several passages on musical matters in Rome. Camille Saint-Saëns, who used to delight the circle at Regnault's studio in Paris by playing for hours from the scores of Wagner, had sent to his friend, in April 1867, a "Veni Creator," in manuscript, with the request that Regnault submit it to Abbé Liszt. Regnault describes his visit with a painter's sensibility. He relates how he rang the bell and felt his heart thump as if he were at the door of the dentist. The Grand Old Man received him with une amabilité charmante, praised the motet, and then played excerpts of his own Dante and his Tasso. Regnault was in the seventh heaven. Who would not have been, in his place? There is an account of an amusing incident in a letter written in January, 1868, the time when the painter was very much occupied with his first envoi, which was "Automedon and the horses of Achilles" and which now hangs in the Boston museum. Regnault says: "My little director" - the painter Hébert-"asked me last Sunday to render him a service which, I confess, cost me a great deal and did not fit in at all with my present state of mind. He had asked the French ambassador to dinner, together with sundry duchesses, countesses and the like. He was to entertain them, in the evening, with a concert of chamber music, performed by the best players of Rome. But the musicians were obliged to attend a rehearsal at the Teatro Apollo that night. M. Hébert, in his distress, and dreading to see his guests sitting around in the salon, yawning, begged me to assume the burden of entertaining his company and to replace the instrumentalists. Although I was in no mood to appear in public, I did my best, so as not to spoil the party. On a été satisfait." That is true modesty, befitting a real artist. What did Regnault sing for his illustrious hearers? Surely a song by Augusta, most likely one by his friend Camille, and possibly one by Emile Pessard whose portrait sketch he made in 1868 . Nor was this the only occasion on which he sang publicly. In March of the same year he sang the tenor part in a requiem mass at the church of Saint-Louis des Français, in Rome, for the unveiling of a monument to the memory of his fellow student Deschamps. All the other singers were professionals. "Les premiers chanteurs et les plus forts instrumentistes de Rome prêtaient leur concours 
et il s'agissait de ne pas faire rougir l'Académie de son ténor. L'église était remplie, et bon nombre d'étrangers avaient été conviés. Tout a bien marché, dit-on. Nous nous sommes couverts de gloire." There is just pride of knowing how in that remark. A future of more glory would have been his, had not a Prussian bullet, perhaps the last one fired before the walls of Paris in 1871, killed the patriot, silenced that "voix si douce et si pentetrante," as Arthur Duparc called it, and robbed the world of an astonishing painter, whose genius had hardly begun to develop.

The Franco-Prussian war cast a deep shadow over artistic relations between the two countries. Wagner's music was banned from Paris before it had time to become established. Pauline Viardot no longer spent her summers at Baden-Baden, but received her friends at the large house in Bougival. Hers was one of the last musical salons of the old school headed by Gounod and Ambroise Thomas. New currents of thought began to make themselves felt. Wagner's works were exiled, but his doctrines permeated everything. Reyer-who when he first came to Paris and called on Théophile Gautier at Neuilly, for an afternoon's visit and a cup of tea, began to talk libretto with the poet and stayed three whole days and nights at Gautier's house, improvising music as fast as Gautier would spin his fantastic yarns for the stage, each stimulating the other's imagination-Reyer had passed the apex of his parabola with "La Statue" in 1861, although "Salammbo" did not come until thirty years later. "Carmen" was first performed on March 3, 1873. Shall we hear Bizet's "Jolie Fille de Perth," or the "Don Procopio," given at Monte Carlo on March 10, 1906? -Then came Massenet with "Le Roi de Lahore" in 1877, with "Manon" in 1884. That was the year in which a young man by the name of Claude Achille Debussy won the Grand Prix de Rome with his cantata "L'Enfant Prodigue." Meanwhile Wagner's influence became ever stronger. Chabrier's "Gwendoline" dates from 1886. Then came the period of "realism" with Emile Zola as high priest, and Bruneau making operas out of Zola's stories. The year of the World's Fair, 1900, brought Charpentier's "Louise." It took him ten years to write it. Another work which was a decade in the making, crowned this extraordinary evolution on April 30, 1902; it was "Pelléas et Mélisande." Most of these names still represent living ideas. But how long can any music last? Already Dr. Burney, wisely and resignedly, wrote: "And shall we expect music to be permanent above all things, which so much depends on imagination and feeling?" Convinced of the merits of our own imagination and feeling, we like to think 
that the masterpieces which we love, be they Couperin's, Chopin's, or Ravel's, will endure. It is interesting to note that the works of the petits maîtres often retain their freshness longer than those of their "bigger" contemporaries. Will Wagner be saved by "Tristan" as Gluck is still saved by "Orpheus"? It is not always the finest flower of a man's brain that recommends him to posterity. Will the composer of "Otello" and "Falstaff" be remembered for an "Anvil Chorus" and the "Manzoni Requiem," as Handel is known to the masses only by a stray opera air, styled "Largo," and by that hardy perennial, "The Messiah"? Puccini will join the shades of Hasse, Jomelli and Piccini. Louise's "Depuis le jour" may survive in concert, as did Leonora's "Abscheulicher, wo eilst du hin?" Such reflections are sad but wholesome. They make us wary in appraising contemporary enthusiasm, give distance to our point of observation. Has Debussy left "The Fall of the House of Usher" and "The Devil in the Belfry" in a condition that will permit their performance? What has become of Charpentier's "Commédiante," his "Tragédiante," his "Symphonie sentimentale: Munich"? Were they all in the satchel which was stolen from him on the train between Vienna and Budapest?

The chapter on lost manuscripts is a long one; that on works out of print is interminable; that on unknown identity quite hopeless. Who has a copy of César Franck's Op. 3 Eglogue, of his Grand Caprice, or his "Souvenir d'Aix-la-Chapelle," and of his Sonata for piano? Who was the mysterious composer of whom Paul Verlaine speaks in his book "Quinze Jours en Hollande"? After a lecture which Verlaine gave during his stay in Amsterdam, he was invited to a reception at the house of the painter Havermann, whose wife, a native of Java, was "très aimable," but who embarrassed poor Lélio on his entrance in the salon by a request which he calls "une demande originale au possible." We are left to guess what the amiable hostess asked of her distinguished guest; nor do we learn the name of the musician described by Verlaine in the following words: "A gentleman opened the soirée by playing us pieces of his own composition in which he seemed to be waging an odd fight with liturgic chants from the Catholic services for the dead." Verlaine heartily approves of this funereal fashion of beginning a social entertainment, since it provides a chance for the mood to rise from the depths of lugubriousness to a high pitch of conviviality and joy, as the night grows longer and memory shorter. The unidentifiable musician with the larve d'ivoire turned out to be more amusing in conversation than at the key- 
board. Verlaine notes with evident satisfaction that the composer proved fertile in anecdote and full of jokes which he told in excellent French. But to Verlaine all art, and possibly all life, was more easily grasped when reduced to terms of alcoholic beverages, and so he sums up his impressions in the delightful comment: "mais c'est égal, sa musique était rudement apéritive." And to think that we shall not be able to procure ourselves this harmless but effective appetizer, in the cocktailless days-of-prohibitionto-come!

Melancholy as these retrospects may be, the thought is even sadder that it will not be possible for us to hear all that the future holds in store. Mingled with this regret there is also something of disquietude. Thomas Alva Edison has delivered us into the hands of posterity. We shall stand utterly revealed, from "That Chicken Pie" to Caruso's Che gelida manina. What will music be like in a hundred years, when the phonographic records of our luminaries, kept sealed in the vaults of the Paris Opera, are solemnly "turned on"? Perhaps I had a foretaste of this, when, not long ago, the idea occurred to me to have two pianos tuned a quarter of a tone apart, with which my friend Arthur Shepherd and I experimented. We had an octave with twenty-four quarter tones. Some of our attempts were blind and sounded meaningless. Others seemed to follow the right direction and disclosed new and wonderful vistas. They produced sonorities of a remarkable richness. Think of the tonal stream that some day will flood your room! In its vague, caressing undulations you shall sit as in a warm and perfumed bath; or in its furious whirl you shall experience divine intoxication. The rule of patterns will be broken. Rhythm may cease to be a thing that you can "beat." Music will have come to its own, it will no longer be a handmaiden of poetry, it will owe nothing to architecture, depend no more on pictorial associations. The soul will speak its very language untranslated. ahead!

This, indeed, is desperate dreaming. Ah, if one could hear 